AperTO - Archivio Istituzionale Open Access dell'Università di Torino

\title{
Lobanovite, $\mathrm{K} 2 \mathrm{Na}(\mathrm{Fe} 2+4 \mathrm{Mg} 2 \mathrm{Na}) \mathrm{Ti2}(\mathrm{Si} 4 \mathrm{O12}) 2 \mathrm{O2}(\mathrm{OH}) 4$, a new mineral of the astrophyllite supergroup and its relation to magnesioastrophyllite
}

\section{This is the author's manuscript}

Original Citation:

Availability:

This version is available http://hdl.handle.net/2318/1557068

since 2016-06-08T11:06:37Z

Published version:

DOI:10.1180/minmag.2016.080.088

Terms of use:

Open Access

Anyone can freely access the full text of works made available as "Open Access". Works made available under a Creative Commons license can be used according to the terms and conditions of said license. Use of all other works requires consent of the right holder (author or publisher) if not exempted from copyright protection by the applicable law. 
5 Lobanovite, $\mathrm{K}_{2} \mathrm{Na}\left(\mathrm{Fe}^{2+}{ }_{4} \mathrm{Mg}_{2} \mathrm{Na}\right) \mathrm{Ti}_{2}\left(\mathrm{Si}_{4} \mathrm{O}_{12}\right)_{2} \mathrm{O}_{2}(\mathrm{OH})_{4}$, a new mineral

6 of the astrophyllite supergroup and its relation to magnesioastrophyllite

9 Elena Sokolova ${ }^{1, *}$, Fernando Cámara ${ }^{2}$, Frank C. Hawthorne ${ }^{1}$, Semenov, E.I ${ }^{3}$. and

10 Marco E. Ciriotti ${ }^{4}$

11

$12{ }^{1}$ Department of Geological Sciences, University of Manitoba, Winnipeg, Manitoba R3T 2N2,

13 Canada

$14{ }^{2}$ Dipartimento di Scienze della Terra, Università degli Studi di Torino, via Valperga Caluso 35, I-

1510125 Torino, Italy

$16{ }^{3}$ Fersman Mineralogical Museum, Russian Academy of Sciences, Leninskii Prospekt, 18-2,

17119071 Moscow, Russia

$18{ }^{4} \mathrm{AMI}$ - Associazione Micromineralogica Italiana, via San Pietro 55, I-10073 Devesi-Ciriè, Italy

22 * Corresponding author, e-mail: elena_sokolova@umanitoba.ca

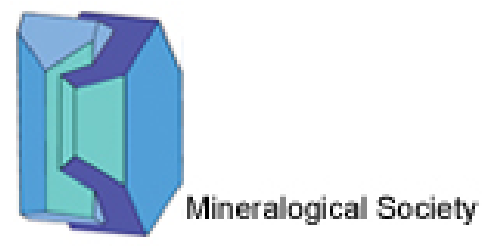




\section{Abstract}

25 Lobanovite, $\mathrm{K}_{2} \mathrm{Na}\left(\mathrm{Fe}^{2+}{ }_{4} \mathrm{Mg}_{2} \mathrm{Na}\right) \mathrm{Ti}_{2}\left(\mathrm{Si}_{4} \mathrm{O}_{12}\right)_{2} \mathrm{O}_{2}(\mathrm{OH})_{4}$, is a new mineral of the astrophyllite 26 supergroup from Mt. Yukspor, the Khibiny alkaline massif, Kola Peninsula Russia. It has been

27 previously known under the following names: monoclinic astrophyllite, magnesium astrophyllite,

28 magnesiumastrophyllite and magnesioastrophyllite but has never been formally proposed and

29 approved as a valid mineral species by the CNMNC-IMA. It has now been revalidated and

30 named lobanovite after Dr. Konstantin V. Lobanov, a prominent Russian ore geologist who

31 worked in Kola Peninsula for more than forty years (Nomenclature voting proposal 15-B).

32 Lobanovite has been described from pegmatitic cavities on Mt. Yukspor where it occurs as

33 elongated bladed crystals, up to $0.04 \mathrm{~mm}$ wide and $0.2 \mathrm{~mm}$ long, with straw yellow to orange

34 colour. Associated minerals are shcherbakovite, lamprophyllite, delindeite, wadeite, umbite and

35 kostylevite. Lobanovite is biaxial (-) with refractive indices $(\lambda=589 \mathrm{~nm}) \alpha=1.658, \beta_{\text {calc. }}=1.687$,

$36 \mathrm{Y}=1.710 ; 2 \mathrm{~V}_{\text {meas. }}=81.5-83^{\circ}$. Lobanovite is monoclinic, space group $C 2 / m$, a $5.3327(2), b$

$3723.1535(9), c 10.3775(4) \AA, \beta 99.615(1)^{\circ}, V 1263.3(1) \AA^{3}, Z=2$. The six strongest reflections in

38 the X-ray powder diffraction data $[d(\AA), \mathrm{I},(h k l)]$ are: 3.38, 100, (003); 2.548, 90, (063); 10.1, 80,

39 (001); 3.80, 60, $(042,131) ; 3.079,50,(132,062) ; 2.763,90,(\overline{171})$. The chemical composition of

40 lobanovite was determined by electron-microprobe analysis and the empirical formula

$41 \quad\left(\mathrm{~K}_{1.97} \mathrm{Ba}_{0.01}\right)_{\Sigma 1.98}\left(\mathrm{Na}_{0.65} \mathrm{Ca}_{0.14}\right)_{\Sigma 0.79}\left(\mathrm{Fe}^{2+}{ }_{3.18} \mathrm{Mg}_{2.02} \mathrm{Na}_{1.00} \mathrm{Mn}_{0.72}\right)_{\Sigma 6.92}\left(\mathrm{Ti}_{1.99} \mathrm{Nb}_{0.06}\right)_{\Sigma 2.05}\left[\left(\mathrm{Si}_{8.01}\right.\right.$

$\left.\left.42 \mathrm{Al}_{0.06}\right)_{\Sigma 8.07} \mathrm{O}_{24}\right]_{2}(\mathrm{OH})_{4.03} \mathrm{~F}_{0.19}$ was calculated on the basis of $30.2(\mathrm{O}+\mathrm{OH}+\mathrm{F})$ anions, with $\mathrm{H}_{2} \mathrm{O}$

43 calculated from structure refinement, $D_{\text {calc. }}=3.161 \mathrm{~g} \mathrm{~cm}^{-3}$. In the structure of lobanovite, the

44 main structural unit is the $\mathrm{HOH}$ block, which consists of one close-packed $\mathrm{O}$ (Octahedral) and

45 two $\mathrm{H}$ (Heteropolyhedral) sheets. The $\mathrm{M}(1-4)$ octahedra form the $\mathrm{O}$ sheet and the $\mathrm{T}_{4} \mathrm{O}_{12}$

46 astrophyllite ribbons and [5]-coordinated Ti-dominant D polyhedra link through common vertices

47 to form the $\mathrm{H}$ sheet. The $\mathrm{HOH}$ blocks repeat along [001], and $\mathrm{K}$ and $\mathrm{Na}$ atoms occur at the

48 interstitial $A$ and $B$ sites. The simplified and endmember formulae of lobanovite are 
$49 \mathrm{~K}_{2} \mathrm{Na}\left[\left(\mathrm{Fe}^{2+}, \mathrm{Mn}\right)_{4} \mathrm{Mg}_{2} \mathrm{Na} \mathrm{Ti}_{2}\left(\mathrm{Si}_{4} \mathrm{O}_{12}\right)_{2} \mathrm{O}_{2}(\mathrm{OH})_{4}\right.$ and $\mathrm{K}_{2} \mathrm{Na}\left(\mathrm{Fe}^{2+}{ }_{4} \mathrm{Mg}_{2} \mathrm{Na}\right) \mathrm{Ti}_{2}\left(\mathrm{Si}_{4} \mathrm{O}_{12}\right)_{2} \mathrm{O}_{2}(\mathrm{OH})_{4}$,

50 respectively.

51

52 Keywords: lobanovite, magnesiumastrophyllite, astrophyllite supergroup, chemical composition,

53 crystal-structure refinement 


\section{Introduction}

55 Lobanovite, $\mathrm{K}_{2} \mathrm{Na}\left(\mathrm{Fe}^{2+}{ }_{4} \mathrm{Mg}_{2} \mathrm{Na}\right) \mathrm{Ti}_{2}\left(\mathrm{Si}_{4} \mathrm{O}_{12}\right)_{2} \mathrm{O}_{2}(\mathrm{OH})_{4}$, is a new mineral of the astrophyllite 56 supergroup from Mt. Yukspor, the Khibiny alkaline massif, Kola Peninsula Russia. It has been

57 previously known under the names monoclinic astrophyllite, magnesium astrophyllite,

58 magnesiumastrophyllite and magnesioastrophyllite (Peng and Ma, 1963; X-ray Laboratory,

59 Hubei Geologic College, 1974; Shi et al., 1998; Piilonen et al., 2003a; Sokolova and Cámara,

60 2008; Cámara et al., 2010) but has never been formally proposed and approved as a valid

61 mineral species by the CNMNC-IMA, although it was discovered in the CNMNC era. It has now

62 been revalidated and named lobanovite after Dr. Konstantin Valentinovich Lobanov (Cyrillic:

63 Константин Валентинович Лобанов; b. 1952, Roslavl', Russia), a prominent Russian ore

64 geologist, DSc. (Doctor of Science, Geology and Mineralogy) and an expert in Precambrian

65 metallogeny. It is particularly appropriate to name this mineral from the Kola Peninsula after Dr.

66 Lobanov, as he worked in the Kola Peninsula for the last 40 years, focusing on the rocks of the

67 Kola superdeep borehole and their relation to the deep structure of ore districts (CNMNC-IMA:

68 Nomenclature voting proposal 15-B). The holotype specimen of lobanovite is the microprobe

69 mount of the single crystal that was used for structure refinement by Sokolova and Cámara

70 (2008) and it was deposited in the collections of the Fersman Mineralogical Museum, Russian

71 Academy of Sciences, Leninskii Prospekt, 18/2, 119071 Moscow, Russia, catalogue number

$724708 / 1$

73 In this paper, we give an overview of previous studies of lobanovite and report a

74 compilation of data from the literature and necessary for a description of lobanovite as a valid

75 mineral species.

\section{Previous work}

78 Semenov (1959) reported on the astrophyllite with unusually high content of MgO (6.39 wt.\%)

79 from the Khibiny alkaline massif, Kola Peninsula, Russia; the complete chemical analysis was 
not given. Peng and Ma (1963) reported a chemical analysis, with the following simplified

81 formula $\mathrm{K}_{2} \mathrm{Na}_{2}\left(\mathrm{Fe}^{2+}, \mathrm{Mn}\right)_{2}\left(\mathrm{Fe}^{2+}, \mathrm{Fe}^{3+}\right)_{3} \mathrm{Mg}_{2} \mathrm{Ti}_{2}\left(\mathrm{Si}_{4} \mathrm{O}_{12}\right)_{2}(\mathrm{O}, \mathrm{OH})_{3}(\mathrm{OH}, \mathrm{F})_{4}, \mathrm{Z}=2$, unit-cell parameters

82 a 10.43(2), b 23.00(5), c 5.35(1) $\AA, \beta 102^{\circ}$, and a preliminary crystal structure in space group

$83 A 2 / m$ (atom coordinates were not reported) for the astrophyllite from Khibiny. X-ray Laboratory,

84 Hubei Geologic College (1974) reported the X-ray powder-diffraction data, DTA data and optical

85 properties for the material mentioned above. The crystal structure of monoclinic astrophyllite

86 was refined by Shi et al. (1998) on sample no. 3086 provided by A. Khomyakov from Mt.

87 Yukspor, the Khibiny alkaline massif, Kola Peninsula, Russia. They gave a full description of the

88 crystal structure, an ideal formula $\mathrm{K}_{2} \mathrm{NaNa}(\mathrm{Fe}, \mathrm{Mn})_{4} \mathrm{Mg}_{2} \mathrm{Ti}_{2}\left(\mathrm{Si}_{4} \mathrm{O}_{12}\right)_{2}(\mathrm{OH})_{4}(\mathrm{OH}, \mathrm{F})_{2}$, and unit-cell

89 parameters, a 10.370(3), b 23.129(5), c 5.322(1) $\AA, \beta 99.55(2)^{\circ}, V 1258.8(5) \AA^{3}$, space group

$90 A 2, Z=2, D_{\text {calc. }}=3.173 \mathrm{~g} / \mathrm{cm}^{-3}$ (this formula has an excess charge of $2^{+}$). The structure data of

91 Shi et al. (1998) is in the International Crystal Structure Database (ICSD) under \#52032. The

92 ICSD revised \#52032 as \#56848, with higher symmetry, space group $A 2 / m$, and a quite different

93 formula: $\mathrm{K}_{1.96} \mathrm{Na}_{2.06} \mathrm{Fe}_{3.72} \mathrm{Mg}_{2.28} \mathrm{Ti}_{2}\left(\mathrm{Si}_{8} \mathrm{O}_{28}\right)\left(\mathrm{H}_{2} \mathrm{O}\right)_{2}$, based on the same work of Shi et al. (1998).

94 The latter formula is neutral but it is chemically and structurally incorrect as $\mathrm{H}_{2} \mathrm{O}$ groups do not

95 occur in magnesium astrophyllite. Piilonen et al. (2003a) considered the structure of magnesium

96 astrophyllite (space group A2) and re-wrote its formula as $\mathrm{K}_{2} \mathrm{Na}\left[\mathrm{Na}(\mathrm{Fe}, \mathrm{Mn})_{4} \mathrm{Mg}_{2}\right] \mathrm{Ti}_{2} \mathrm{Si}_{8} \mathrm{O}_{26}$

$97(\mathrm{OH})_{4} \square$. Although the ICSD \#56848 points out that the possible space group might be $A 2 / m$,

98 the crystal structure of magnesium astrophyllite has not been re-investigated since the work of

99 Shi et al. (1998). Following the inconsistency between the chemical composition and structure

100 for magnesium astrophyllite in the ICSD (see above), Sokolova and Cámara (2008) refined the

101 crystal structure of magnesium astrophyllite (see below) and reported the chemical composition

102 of the crystal of magnesium astrophyllite used for structure refinement. They confirmed the

103 general topology of the crystal structure described by Shi et al. (1998) and gave the ideal

104 formula of magnesium astrophyllite as follows: $\mathrm{K}_{2} \mathrm{Na}\left(\mathrm{Fe}_{4} \mathrm{Mg}_{2} \mathrm{Na}\right)^{[5]} \mathrm{Ti}_{2} \mathrm{Si}_{8} \mathrm{O}_{26}(\mathrm{OH})_{4}$. Cámara et al.

105 (2010) suggested writing the astrophyllite-ribbon component of the formula as $\left(\mathrm{Si}_{4} \mathrm{O}_{12}\right)_{2} \mathrm{O}_{2}$ 
versus $\mathrm{Si}_{8} \mathrm{O}_{26}$ [Piilonen et al. (2003a)]. They emphasized that (1) the translational repeat

107 fragment of the ribbon has the formula $\mathrm{Si}_{4} \mathrm{O}_{12} ;(2)$ there are two ribbons (corresponding to two $\mathrm{H}$ 108 sheets) attached to the central $\mathrm{O}$ sheet; (3) the $\mathrm{O}_{2}$ anions do not link to $\mathrm{Si}$, and this information 109 should be preserved in the chemical formula by writing them separately from the silicate radical.

110 Cámara et al. (2010) wrote the formula of magnesiumastrophyllite as $\mathrm{K}_{2} \mathrm{Na}\left(\mathrm{Fe}_{4}\right.$

$\left.111 \mathrm{Mg}_{2} \mathrm{Na}\right) \mathrm{Ti}_{2}\left(\mathrm{Si}_{4} \mathrm{O}_{12}\right)_{2} \mathrm{O}_{2}(\mathrm{OH})_{4}$. Burke (2008) renamed magnesium astrophyllite and/or

112 magnesiumastrophyllite as magnesioastrophyllite. Sokolova (2012) showed that the topology of

113 the $\mathrm{HOH}$ block in magnesioastrophyllite is different from all other structures of the astrophyllite-

114 supergroup minerals due to the different chemical composition of the $\mathrm{O}$ sheet $\left(\mathrm{Fe}^{2+}{ }_{4} \mathrm{Mg}{ }_{2} \mathrm{Na}\right)$,

115 particularly the dominance of $\mathrm{Na}^{+}$at the $M(1)$ site which makes the $\mathrm{M}(1)$ polyhedron too large to

116 share edges with $\mathrm{Si}_{2} \mathrm{O}_{7}$ groups of astrophyllite ribbons and results in a different linkage of $\mathrm{H}$ and

117 O sheets, i.e. a different topology of the $\mathrm{HOH}$ block. She wrote the ideal formula of

118 magnesioastrophyllite as follows: $\mathrm{K}_{2} \mathrm{Na}\left(\mathrm{Fe}^{2+}{ }_{4} \mathrm{Mg}_{2} \mathrm{Na}\right) \mathrm{Ti}_{2}\left(\mathrm{Si}_{4} \mathrm{O}_{12}\right)_{2} \mathrm{O}_{2}(\mathrm{OH})_{4}$ and emphasized that

119 the name magnesioastrophyllite is misleading as it is the dominance of $\mathrm{Na}^{+}$at the $M(1)$ site that 120 results in the different topology of the $\mathrm{HOH}$ block [not the dominance of $\mathrm{Mg}^{2+}$ at the $M(4)$ site].

121 Further on in the paper, we will use only the name lobanovite and compare its properties 122 and structure to those of astrophyllite (Table 1).

\section{Occurrence and mineral association}

125 Sokolova and Cámara (2008) refined the crystal structure and determined the chemical

126 composition of lobanovite on the same single crystal taken from the sample of delindeite in the

127 collection of minerals of Adriana and Renato Pagano, Milan, Italy (Collezione Mineralogica,

128 sample \#6270). This sample came from Alexander Khomyakov and was described in

129 Khomyakov (1995). Hence we use his description for the occurrence and associated minerals. 
Lobanovite was found in pegmatite cavities at Mt. Yukspor, the Khibiny alkaline massif,

131 Kola Peninsula, Russia. Associated minerals are shcherbakovite, lamprophyllite, delindeite,

132 wadeite, umbite, kostylevite and other species [taken from Khomyakov (1995), p. 151].

\section{Physical properties}

137 Lobanovite occurs as elongated bladed crystals, with straw yellow (Anthony et al., 1995) to 138 orange colour (Sokolova and Cámara, 2008) up to $0.04 \mathrm{~mm}$ wide and $0.2 \mathrm{~mm}$ long, with a 139 vitreous luster and a white to yellowish-white streak. The mineral has Mohs hardness of 3 , 140 perfect cleavage parallel to (001) and moderate cleavage parallel to (010). Twinning, parting 141 and fracture have not been observed (Anthony et al., 1995). Lobanovite does not fluoresce 142 under SW or LW ultraviolet light, $D_{\text {calc. }}=3.161 \mathrm{~g} / \mathrm{cm}^{3}$ (from the empirical formula of Sokolova

143 and Cámara, 2008). Lobanovite is optically biaxial $(-), \alpha=1.658, \beta=1.687_{\text {calc. }}, y=1.710(589$

$144 \mathrm{~nm}$ ), with $2 \mathrm{~V}_{\text {meas. }}=81.5-83^{\circ}$. The pleochroism: $X=$ bright yellow, $Y=$ pale yellowish grey, $Z=$

145 grey, with the absorption scheme: $Z<Y<X$ and orientation $Y=b, Z \wedge a=-5$ to $-6^{\circ}$ (X-ray

146 Laboratory, Hubei Geological College, 1974). DTA curve shows endothermic peaks at $835^{\circ} \mathrm{C}$

147 (strong, escape of $\mathrm{OH}$ ) and $900^{\circ} \mathrm{C}$ (weak) (X-ray Laboratory, Hubei Geologic College, 1974).

$148 \quad$ The compatibility index was calculated using the chemical analysis and unit-cell

149 parameters of Sokolova and Cámara (2008) and optical properties from X-ray Laboratory, Hubei

150 Geological College (1974): $1-\left(\mathrm{K}_{\mathrm{p}} / \mathrm{K}_{\mathrm{c}}\right)$ is 0.057 and is rated as good (Mandarino, 1981).

\section{Chemical composition}

153 Sokolova and Cámara (2008) determined the chemical composition of lobanovite using a

154 Cameca SX100 electron microprobe (WDS mode, 15 kV, 20 nA, $10 \mu \mathrm{m}$ beam diameter). Ta, Zr, $155 \mathrm{Sn}, \mathrm{Zn}, \mathrm{Cs}, \mathrm{Rb}, \mathrm{Sr}$ and $\mathrm{Pb}$ were sought but not detected [for details, see Sokolova and Cámara 
156 (2008)]. The content of $\mathrm{H}_{2} \mathrm{O}$ (wt. \%) was calculated by stoichiometry from the results of the

157 crystal-structure refinement. The chemical composition of lobanovite is given in Table 2 (mean

158 of 10 analyses) in comparison with that of the X-ray Laboratory, Hubei Geologic College (1974).

159 Sokolova and Cámara (2008) calculated the empirical formula on the basis of $30.2(\mathrm{O}+\mathrm{OH}+\mathrm{F})$

160 anions which include $30(\mathrm{O}+\mathrm{OH})$ p.f.u. and $0.2 \mathrm{~F}$ a.p.f.u. (atoms per formula unit). The

161 empirical, simplified and endmember formulae are $\left(\mathrm{K}_{1.97} \mathrm{Ba}_{0.01}\right)_{\Sigma 1.98}\left(\mathrm{Na}_{0.65} \mathrm{Ca}_{0.14}\right)_{\Sigma 0.79}$

$162\left(\mathrm{Fe}^{2+}{ }_{3.18} \mathrm{Mg}_{2.02} \mathrm{Na}_{1.00} \mathrm{Mn}_{0.72}\right)_{\Sigma 6.92}\left(\mathrm{Ti}_{1.99} \mathrm{Nb}_{0.06}\right)_{\Sigma 2.05}\left[\left(\mathrm{Si}_{8.01} \mathrm{Al}_{0.06}\right)_{\Sigma 8.07} \mathrm{O}_{24}\right] \mathrm{O}_{2}(\mathrm{OH})_{4.03} \mathrm{~F}_{0.19}, \mathrm{Z}=2$,

$163 \mathrm{~K}_{2} \mathrm{Na}\left[\left(\mathrm{Fe}^{2+}, \mathrm{Mn}\right)_{4} \mathrm{Mg}_{2} \mathrm{Na}_{\mathrm{Ti}}\left(\mathrm{Si}_{4} \mathrm{O}_{12}\right)_{2} \mathrm{O}_{2}(\mathrm{OH})_{4}\right.$ and $\mathrm{K}_{2} \mathrm{Na}\left(\mathrm{Fe}^{2+}{ }_{4} \mathrm{Mg}_{2} \mathrm{Na}\right) \mathrm{Ti}_{2}\left(\mathrm{Si}_{4} \mathrm{O}_{12}\right)_{2} \mathrm{O}_{2}(\mathrm{OH})_{4}$,

164 respectively.

\section{X-ray powder-diffraction data}

167 X-ray powder-diffraction data are presented in Table 3.

Crystal structure

170 Sokolova and Cámara (2008) refined the crystal structure of lobanovite to $R_{1}=3.2 \%$ on the

171 basis of 1861 unique reflections $\left(F_{0}>4 \sigma F\right)$ collected on a Bruker AXS SMART APEX

172 diffractometer with a CCD detector and MoKa-radiation: space group C2/m, a 5.3327(2), $b$

173 23.1535(9), c 10.3775(4)Å, $\beta$ 99.615(1) ${ }^{\circ}, V 1263.3(1) \AA^{3}, Z=2, D_{\text {calc. }} 3.161$ g.cm ${ }^{-3}$ (Table 4)

174 from Mt. Yukspor, Khibina alkaline massif, Kola Peninsula, Russia. The main structural unit in

175 the structure of lobanovite is the $\mathrm{HOH}$ block which consists of a central close-packed $\mathrm{O}$

176 (Octahedral) and two adjacent $\mathrm{H}$ (Heteropolyhedral) sheets. In the O sheet, there are four [6]-

177 coordinated $M(1-4)$ sites occupied by $\mathrm{Na}, \mathrm{Fe}^{2+}{ }_{1.25} \mathrm{Mn}_{0.75}, \mathrm{Fe}^{2+}{ }_{1.20} \mathrm{Mg}_{0.80}$ and $\mathrm{Mg}_{1.25} \mathrm{Fe}^{2+}{ }_{0.75}$, with

$178<\mathrm{M}(1,2,3,4)-\mathrm{O}>=2.372,2.166,2.113$ and $2.094 \AA$, respectively (Fig. 1a, Table 5). The ideal

179 composition of the $\mathrm{O}$ sheet is $\left(\mathrm{Fe}^{2+}{ }_{4} \mathrm{Mg}_{2} \mathrm{Na}\right) \mathrm{O}_{2}(\mathrm{OH})_{4}$ p.f.u. In the $\mathrm{H}$ sheet, there is one [5]-

180 coordinated $D$ site occupied by $\mathrm{Ti}_{1.97} \mathrm{Nb}_{0.03}$, with $<\mathrm{D}-\mathrm{O}>=1.907 \AA$, and there are two 
181 tetrahedrally coordinated $T$ sites occupied primarily by Si with minor Al, with $<\mathrm{T}-\mathrm{O}>=1.625 \AA$.

$182 \mathrm{TO}_{4}$ tetrahedra form $\mathrm{T}_{4} \mathrm{O}_{12}$ astrophyllite ribbons extending along a. Astrophyllite ribbons and [5]-

183 coordinated D polyhedra connect through common vertices to form the $\mathrm{H}$ sheet. The ideal

184 composition of the two $\mathrm{H}$ sheets is $\mathrm{Ti}_{2}\left(\mathrm{Si}_{4} \mathrm{O}_{12}\right)_{2}$ p.f.u. An O sheet and two adjacent $\mathrm{H}$ sheets link

185 through common vertices of $\mathrm{TO}_{4}$ tetrahedra, $\mathrm{D}$ octahedra and $\mathrm{M}$ octahedra to form an $\mathrm{HOH}$

186 block parallel to (001) (Fig. 1a). The HOH blocks alternate with I (Intermediate) blocks along c

187 (Fig. 1b). In the I block, there are two interstitial sites, a [10]-coordinated $A$ site and an [8]-

188 coordinated $B$ site occupied by $\mathrm{K}_{1.96} \mathrm{Ba}_{0.01} \square_{0.03}$ and $\mathrm{Na}_{0.65} \mathrm{Ca}_{0.14} \square_{0.21}$, respectively, with $<\mathrm{A}-\mathrm{O}>=$

1893.120 and $\langle\mathrm{B}-\mathrm{O}\rangle=2.536 \AA$ (Table 5). The ideal composition of the I block is $\mathrm{K}_{2} \mathrm{Na}$ a.p.f.u.

190 Cations at the $A$ and $B$ sites form a layer parallel to (001) (Fig. $1 b$ ). The presence of the partly

191 occupied $F$ site makes $17 \%$ of the $A$ and $B$ sites [11]- and [10]-coordinated, respectively (Table

$1925)$.

193 The general topology of the lobanovite structure is in accord with Shi et al. (1998). The

194 topology of the $\mathrm{HOH}$ block in lobanovite differs from all other structures of the astrophyllite-

195 supergroup minerals (for the astrophyllite structure, see Fig. $2 a$ in Sokolova et al., 2015) due to

196 the chemical composition of the $\mathrm{O}$ sheet, $\mathrm{Fe}^{2+}{ }_{4} \mathrm{Mg}_{2} \mathrm{Na}$, where $\mathrm{Na}^{+}$is dominant at the $M(1)$ site

197 (Sokolova, 2012). Hence the $\mathrm{Na}$ octahedron is too large to share edges with $\mathrm{Si}_{2} \mathrm{O}_{7}$ groups of

198 astrophyllite ribbons resulting in a different linkage of $\mathrm{H}$ and $\mathrm{O}$ sheets, i.e. a different topology of

199 the $\mathrm{HOH}$ block [cf. Si-Si distances associated with the $\mathrm{Na}$ octahedron $(3.96 \AA)$ and the $\mathrm{Fe}^{2+}$

200 octahedron (3.06 Å), Fig. 1a].

201

202 Acknowledgements

203 Authors are grateful to two anonymous reviewers for their comments and Principal Editor Pete

204 Williams for handling the manuscript. We thank the vice president of the CNMNC-IMA Frédéric

205 Hatert and members of the Commission for useful comments and suggestions. FC

206 acknowledges support by the University of Torino "Progetti di ricerca finanziati dall'Università 
207 degli Studi di Torino (ex 60 \%)"- year 2014. This work was also supported by a Canada

208 Research Chair in Crystallography and Mineralogy and by a Discovery grant from the Natural

209 Sciences and Engineering Research Council of Canada to FCH, and by Innovation Grants from

210 the Canada Foundation for Innovation to $\mathrm{FCH}$. 
212 Anthony, J.W., Bideaux, R.A., Bladh, K.W. and Nichols, M.C. (1995) Handbook of Mineralogy. II. Silica, Silicates. Mineral Data Publishing, Tucson, p. 505.

214 Burke, E.A.J. (2008) Tidying up mineral names: an IMA-CNMNC scheme for suffixes, hyphens 215 and diacritical marks. Mineralogical Record, 39, 131-135.

216 Cámara, F., Sokolova, E., Abdu, Y. and Hawthorne, F.C. (2010) The crystal structures of niobophyllite, kupletskite-(Cs) and Sn rich astrophyllite; revisions to the crystal chemistry

Khomyakov, A.P. (1995) Mineralogy of Hyperagpaitic Alkaline Rocks. Clarendon Press, Ed.,

Mandarino, J.A. (1981) The Gladstone-Dale relationship. Part IV. The compatibility concept and its application. The Canadian Mineralogist, 19, 441-450.

Peng, S. and Ma. Z. (1963) The discovery of a new type of an Si-O ribbon - crystal-structure analysis of astrophyllite. Scientica Sinica, 12, 272-276 (in Russian).

Piilonen, P.C., LaLonde, A.E., McDonald, A.M., Gault, R.A. and Larsen, A.O. (2003a) Insights into astrophyllite-group minerals. I. Nomenclature, composition and development of a standardized general formula. The Canadian Mineralogist, 41, 1-26.

Semenov, E.I. (1959) Lithian and other micas and hydro-micas in alkaline pegmatites of Kola Peninsula. Trudy Mineralogicheskogo Muzeya, N9, 107-137 (in Russian).

232 Shannon, R.D. (1976) Revised effective ionic radii and systematic studies of interatomic distances in halides and chalcogenides. Acta Crystallographica, A32, 751-767.

234 Shi, N., Ma, Z., Li, G., Yamnova, N.A. and Pushcharovsky, D.Y. (1998) Structure refinement of monoclinic astrophyllite. Acta Crystallographica, B54, 109-114. 
236 Sokolova, E. (2012) Further developments in the structure topology of the astrophyllite-group 237 minerals. Mineralogical Magazine, 76, 863-882.

238 Sokolova, E., Cámara, F., Hawthorne, F.C. and Ciriotti, M.E. (2015) The astrophyllite 239 supergroup: nomenclature and classification. Mineralogical Magazine (accepted).

240 Sokolova, E. and Cámara, F. (2008) Re-investigation of the crystal structure of magnesium

241 astrophyllite. European Journal of Mineralogy, 20, 253-260.

242 X-ray Laboratory, Hubei Geologic College (1974) The crystal chemistry of astrophyllite group 243 minerals. Scientica Sinica, 1, 18-33 (in Chinese). 


\section{Figure captions}

247 Fig. 1. The crystal structure of lobanovite: (a) the $\mathrm{HOH}$ block viewed perpendicular to the plane 248 of the block [after Fig. 6a of Sokolova (2012)]; (b) general view of the crystal structure of

249 lobanovite [after Fig. $2 b$ of Sokolova (2012)]. The [5]-coordinated Ti polyhedra and $\mathrm{Fe}^{2+}-$ and

250 Mg-dominant octahedra are pale yellow, green and pink; Na octahedra are navy blue; Si

251 tetrahedra are orange; $\mathrm{K}$ and $\mathrm{Na}$ atoms at the $A$ and $B$ sites are shown as green and blue 252 spheres; $\mathrm{OH}$ groups are shown as small red spheres. The position of the cation layer in the I

253 (Intermediate) block ( $\mathrm{m}=1$, where $\mathrm{m}$ is a number of cation layers) is shown by a turquoise line. 254 
Table 1. Comparison of lobanovite and astrophyllite

\begin{tabular}{|c|c|c|}
\hline & Lobanovite* & Astrophyllite ${ }^{* *}$ \\
\hline Formula & $\begin{array}{l}\mathrm{K}_{2} \mathrm{Na}\left(\mathrm{Fe}^{2+}{ }_{4} \mathrm{Mg}_{2} \mathrm{Na}\right) \mathrm{Ti}_{2} \\
\left(\mathrm{Si}_{4} \mathrm{O}_{12}\right)_{2} \mathrm{O}_{2}(\mathrm{OH})_{4}\end{array}$ & $\begin{array}{l}\mathrm{K}_{2} \mathrm{NaFe}^{2+}{ }_{7} \mathrm{Ti}_{2} \\
\left(\mathrm{Si}_{4} \mathrm{O}_{12}\right)_{2} \mathrm{O}_{2}(\mathrm{OH})_{4} \mathrm{~F}\end{array}$ \\
\hline System & monoclinic & triclinic \\
\hline Space group & $\mathrm{C} 2 / \mathrm{m}$ & $P \overline{1}$ \\
\hline$a(\AA)$ & $5.3327(2)$ & $5.36-5.42$ \\
\hline$b$ & $23.1535(9)$ & $11.85-11.95$ \\
\hline$c$ & $10.3775(4)$ & $11.66-11.75$ \\
\hline$\alpha\left(^{\circ}\right)$ & 90 & 112.03-113.13 \\
\hline$\beta$ & $99.615(1)$ & $94.52-94.64$ \\
\hline Y & 90 & 103.08-103.14 \\
\hline$V\left(\AA^{3}\right)$ & 1263.3(1) & $652.9-668.5$ \\
\hline$Z$ & 2 & 1 \\
\hline $\begin{array}{l}D_{\text {meas }} / D_{\text {calc. }} \\
\left(\mathrm{g} \mathrm{cm}^{-3}\right)\end{array}$ & n.d./3.161 & $3.09-3.23 / 3.35$ \\
\hline $\begin{array}{l}\text { Strongest refl. } \\
\text { in powder } \\
\text { diffraction data } \\
d_{\text {obs. }}(\AA)(I)\end{array}$ & $\begin{array}{l}3.38(100), 2.548(90) \\
10.1(80), 3.80(60) \\
3.079(50), 2.763(50)\end{array}$ & $\begin{array}{l}10.6(100), 3.51(80), \\
2.77(60), 2.64(60), \\
2.57(60), 1.76(30)\end{array}$ \\
\hline $\begin{array}{l}\text { Optical } \\
\text { character }\end{array}$ & biaxial $(-)$ & biaxial $(+)$ \\
\hline$\alpha$ & 1.658 & $1.678-1.695$ \\
\hline$\beta$ & 1.687 & $1.703-1.726$ \\
\hline $\mathrm{Y}$ & 1.710 & $1.733-1.758$ \\
\hline $2 \mathrm{~V}_{\text {meas }}\left({ }^{\circ}\right)$ & $81.5-83$ & $66-84$ \\
\hline Colour & Yellow to orange & $\begin{array}{l}\text { Bronze yellow to golden } \\
\text { yellow, brown to reddish } \\
\text { brown }\end{array}$ \\
\hline Pleochroism & $\begin{array}{l}X=\text { bright yellow } \\
Y=\text { pale yellowish grey } \\
Z=\text { grey }\end{array}$ & $\begin{array}{l}X=\text { deep orange red } \\
Y=\text { orange yellow } \\
Z=\text { lemon yellow }\end{array}$ \\
\hline
\end{tabular}

${ }^{*}$ All data are from Sokolova and Cámara (2008) except for powder diffraction data and optical properties (X-ray laboratory, Hubei Geologic college 1974);

${ }^{* *}$ Data from Anthony et al. (1995) except for cell parameters (Piilonen et al., 2003b) 
Table 2. Chemical composition of lobanovite

\begin{tabular}{|c|c|c|c|c|c|}
\hline Constituent & wt. \% & & Range (wt.\%) & SD (wt.\%) & Probe Standard \\
\hline & $\begin{array}{c}\text { X-ray Lab., } \\
\text { Hubei Geologic } \\
\text { College (1974) }\end{array}$ & & — Sokolova and & Cámara (20 & 008) \\
\hline $\mathrm{Nb}_{2} \mathrm{O}_{5}$ & n.a & 0.64 & $0.29-1.22$ & 0.31 & $\mathrm{Ba}_{2} \mathrm{NaNb}_{5} \mathrm{O}_{15}$ \\
\hline $\mathrm{TiO}_{2}$ & 12.18 & 13.11 & $12.47-13.48$ & 0.31 & titanite \\
\hline $\mathrm{SiO}_{2}$ & 37.98 & 39.72 & $39.43-39.92$ & 0.18 & diopside \\
\hline $\mathrm{Al}_{2} \mathrm{O}_{3}$ & 1.11 & 0.24 & $0.08-0.42$ & 0.13 & andalusite \\
\hline $\mathrm{Fe}_{2} \mathrm{O}_{3}$ & 2.95 & n.d. & & & \\
\hline $\mathrm{BaO}$ & n.a. & 0.13 & $0.04-0.19$ & 0.04 & baryte \\
\hline $\mathrm{FeO}$ & 17.91 & 18.86 & $17.98-21.05$ & 0.84 & fayalite \\
\hline $\mathrm{MnO}$ & 4.00 & 4.21 & $3.10-4.59$ & 0.45 & spessartine \\
\hline $\mathrm{CaO}$ & 1.15 & 0.65 & $0.59-0.82$ & 0.06 & diopside \\
\hline $\mathrm{MgO}$ & 6.39 & 6.72 & $6.05-6.93$ & 0.24 & forsterite \\
\hline $\mathrm{K}_{2} \mathrm{O}$ & 7.28 & 7.66 & $7.54-7.78$ & 0.07 & orthoclase \\
\hline $\mathrm{Na}_{2} \mathrm{O}$ & 5.38 & 4.22 & $4.10-4.29$ & 0.07 & jadeite \\
\hline $\mathrm{H}_{2} \mathrm{O}$ & 3.44 & $3.00^{*}$ & & & \\
\hline $\mathrm{F}$ & 0.45 & 0.29 & $0.17-0.43$ & 0.07 & F- riebeckite \\
\hline $\mathrm{O}=\mathrm{F}$ & -0.19 & -0.12 & & & \\
\hline Total & 100.03 & 99.33 & & & \\
\hline
\end{tabular}


Table 3. Powder diffraction data for lobanovite*

\begin{tabular}{|c|c|c|c|}
\hline $\mathrm{I}_{\text {obs. }}$ & $d_{\text {obs. }}(\AA)$ & $d_{\text {calc. }}(\AA)$ & $h k l$ \\
\hline 80 & 10.1 & 10.22 & 001 \\
\hline \multirow[t]{2}{*}{60} & 3.80 & 3.83 & 042 \\
\hline & & 3.82 & 131 \\
\hline 100 & 3.38 & 3.41 & 003 \\
\hline \multirow[t]{2}{*}{50} & 3.079 & 3.11 & 132 \\
\hline & & 3.08 & 062 \\
\hline 30 & 2.889 & 2.882 & -133 \\
\hline 50 & 2.763 & 2.764 & -171 \\
\hline 90 & 2.548 & 2.554 & 063 \\
\hline 20 & 2.350 & 2.369 & 172 \\
\hline 30 & 2.260 & 2.265 & -173 \\
\hline 30 & 2.040 & 2.047 & 005 \\
\hline 50 & 1.818 & 1.805 & 1111 \\
\hline 50 & 1.727 & 1.727 & -175 \\
\hline 40 & 1.657 & 1.654 & 0140 \\
\hline 10 & 1.591 & 1.592 & 2102 \\
\hline 20 & 1.525 & 1.517 & -176 \\
\hline 70 & 1.463 & 1.461 & 007 \\
\hline 40 & 1.404 & 1.402 & 176 \\
\hline & & 1.400 & 2140 \\
\hline 10 & 1.373 & 1.379 & -207 \\
\hline$\pi$ & 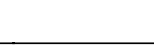 & 1.371 & 2141 \\
\hline
\end{tabular}


Table 4. Final atom coordinates and equivalent displacement parameters for lobanovite [from Sokolova and Cámara (2008)]

\begin{tabular}{lccll}
\hline Atom & $x$ & $y$ & $z$ & $U_{\text {eq }}\left(\AA^{2}\right)$ \\
\hline $\mathrm{M}(1)$ & 0 & 0 & 0 & $0.0129(3)$ \\
$\mathrm{M}(2)$ & $1 / 2$ & $0.07440(2)$ & 0 & $0.0093(2)$ \\
$\mathrm{M}(3)$ & 0 & $0.14505(2)$ & 0 & $0.0091(2)$ \\
$\mathrm{M}(4)$ & $1 / 2$ & $0.21399(3)$ & 0 & $0.0098(2)$ \\
$\mathrm{D}$ & $0.43702(8)$ & 0 & $0.28713(4)$ & $0.0064(2)$ \\
$\mathrm{T}(1)$ & $0.07901(9)$ & $0.21773(2)$ & $0.73587(5)$ & $0.0073(1)$ \\
$\mathrm{T}(2)$ & $0.07573(9)$ & $0.08555(2)$ & $0.72932(5)$ & $0.0076(1)$ \\
$\mathrm{A}$ & $1 / 2$ & $0.13847(4)$ & $1 / 2$ & $0.0267(3)$ \\
$\mathrm{B}$ & 0 & 0 & $1 / 2$ & $0.0103(3)$ \\
$\mathrm{O}(1)$ & $0.4035(4)$ & 0 & $0.1178(2)$ & $0.0107(4)$ \\
$\mathrm{O}(2)$ & $0.1393(3)$ & $0.08202(7)$ & $0.8868(1)$ & $0.0109(3)$ \\
$\mathrm{O}(3)$ & $0.2982(3)$ & $0.05764(7)$ & $0.6609(1)$ & $0.0152(3)$ \\
$\mathrm{O}(4)$ & $0.1966(3)$ & $0.05755(7)$ & $0.3287(2)$ & $0.0170(3)$ \\
$\mathrm{O}(5)$ & $0.0537(3)$ & $0.15325(6)$ & $0.6769(2)$ & $0.0161(3)$ \\
$\mathrm{O}(6)$ & $0.1298(3)$ & $0.21770(6)$ & $0.8930(1)$ & $0.0096(3)$ \\
$\mathrm{O}(7)$ & $0.8141(3)$ & $0.74859(7)$ & $0.6781(1)$ & $0.0139(3)$ \\
$\mathrm{O}(8)$ & $0.3656(3)$ & $0.14762(6)$ & $0.1030(1)$ & $0.0115(3)$ \\
$\mathrm{H}$ & $0.386(6)$ & $0.142(1)$ & $0.191(1)$ & $0.0138(0)^{*}$ \\
$\mathrm{~F}$ & $1 / 2$ & 0 & $1 / 2$ & $0.009(4)^{*}$ \\
\hline${ }^{*} U_{\text {iso. }}$ & & & &
\end{tabular}


Table 5. Refined site-scattering and assigned site-populations for lobanovite [from Sokolova and Cámara (2008)]

\begin{tabular}{|c|c|c|c|c|c|}
\hline$\overline{\text { Site }}$ & $\begin{array}{l}\text { Refined site- } \\
\text { scattering } \\
\text { (e.p.f.u.) }\end{array}$ & $\begin{array}{l}\text { Assigned site- } \\
\text { population } \\
\text { (a.p.f.u.) }\end{array}$ & $\begin{array}{l}\text { Calculated site- } \\
\text { scattering } \\
\text { (e.p.f.u.) }\end{array}$ & $\begin{array}{l}\langle X-\varphi\rangle_{\text {calc. }}{ }^{*} \\
(\AA)\end{array}$ & $\begin{array}{l}<X-\varphi>_{\text {obs. }} \\
(\AA)\end{array}$ \\
\hline${ }^{\left[{ }^{6]} M(1)\right.}$ & $11.0(4)$ & $1.00 \mathrm{Na}$ & 11.0 & 2.400 & 2.372 \\
\hline${ }^{[6]} M(2)$ & $50.0(1)$ & $1.25 \mathrm{Fe}^{2+}+0.75 \mathrm{Mn}$ & 51.3 & 2.169 & 2.166 \\
\hline${ }^{[6]} M(3)$ & $39.7(1)$ & $1.20 \mathrm{Fe}^{2+}+0.80 \mathrm{Mg}$ & 40.8 & 2.126 & 2.113 \\
\hline${ }^{[6]} M(4)$ & $34.1(1)$ & $1.25 \mathrm{Mg}+0.75 \mathrm{Fe}^{2+}$ & 34.5 & 2.090 & 2.094 \\
\hline $\begin{array}{l}{ }^{[5]} D \\
{ }^{[6]} D^{* *}\end{array}$ & $44.4(1)$ & $1.97 \mathrm{Ti}+0.03 \mathrm{Nb}$ & 44.6 & $\begin{array}{l}1.891 \\
1.975\end{array}$ & $\begin{array}{l}1.907 \\
1.952\end{array}$ \\
\hline $\begin{array}{l}{ }^{[10]} A \\
{ }^{[11]} A^{* *}\end{array}$ & $37.8(2)$ & $1.96 \mathrm{~K}+0.01 \mathrm{Ba}+0.03 \square$ & 37.8 & & $\begin{array}{l}3.120 \\
3.127\end{array}$ \\
\hline 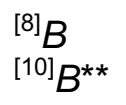 & $12.4(2)$ & $0.65 \mathrm{Na}+0.14 \mathrm{Ca}+0.21 \square$ & 10.0 & & $\begin{array}{l}2.536 \\
2.562\end{array}$ \\
\hline$F$ & $1.5(1)$ & $0.83 \square+0.17 \mathrm{~F}$ & 1.5 & & \\
\hline
\end{tabular}



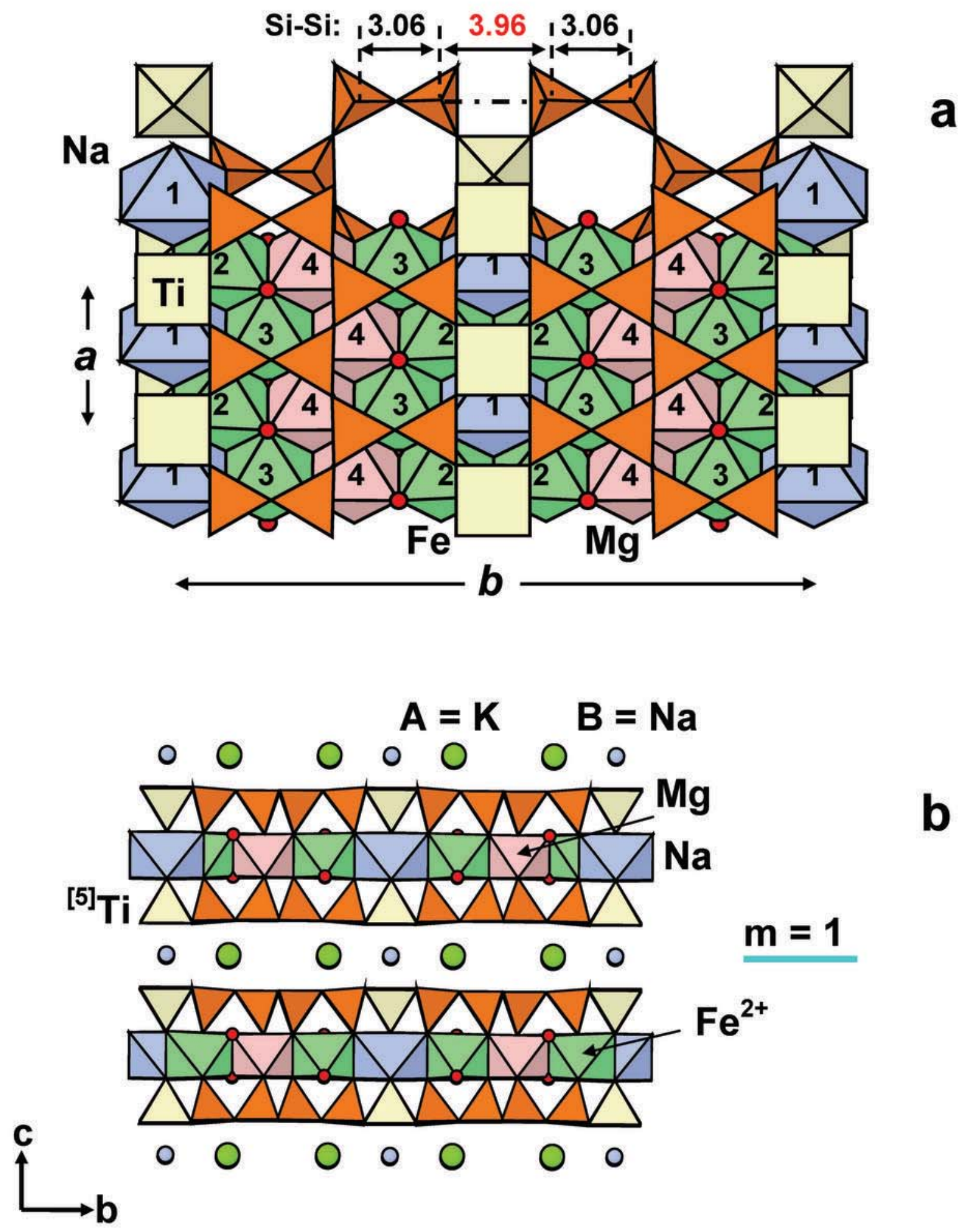

Fig. 1 